\title{
The B chromosome polymorphism of the grasshopper Eyprepocnemis plorans in North Africa. I. B variants and frequency
}

\author{
M. BAKKALI, J. CABRERO, M. D. LÓPEZ-LEÓN, F. PERFECTTI \& J. P. M. CAMACHO* \\ Departamento de Genética, Facultad de Ciencias, Universidad de Granada, E-18071 Granada, Spain
}

\begin{abstract}
Polymorphism for B chromosomes has been detected in all nine populations of the grasshopper Eyprepocnemis plorans ssp. plorans sampled in Morocco. The most frequent B chromosome in all populations showed a $\mathrm{C}$-banding pattern and size similar to those of the $\mathrm{B}_{1}$ variant found in the Iberian Peninsula. In addition, other $B$ chromosome variants $\left(\mathrm{B}_{1 \text { iso } 1}, \mathrm{~B}_{1 \mathrm{iso} 2}, \mathrm{~B}_{1 \mathrm{~d} 1}, \mathrm{~B}_{1 \mathrm{di} 1}, \mathrm{~B}_{3}\right.$ and $\left.\mathrm{B}_{1 \mathrm{dd} 1}\right)$ were discovered in these populations, although at a very low frequency. No significant differences in $B$ chromosome frequency were found either in the nine populations or, for some of them, in up to three consecutive years. These results are discussed in the light of current hypotheses on the evolution of this B chromosome polymorphism in the Iberian Peninsula.
\end{abstract}

Keywords: B chromosomes, Eyprepocnemis plorans ssp. plorans, grasshopper, Orthoptera.

\section{Introduction}

B chromosomes, also called accessory or supernumerary chromosomes, are large pieces of dispensable independently segregating DNA (Camacho et al., 1997a,b). Reported in more than 1300 plant species and nearly 500 animal species (Jones \& Puertas, 1993), variation in the number and morphology of $\mathrm{B}$ chromosomes is a frequent chromosomal polymorphism found in natural populations of many eukaryote organisms. B chromosomes show extensive variation in size and morphology, and most of them are heterochromatic with a variety of different responses to C-banding. Because of their harmful effects on carriers, most of them are considered genome parasites (Östergren, 1945; Müntzing, 1963; Nur, 1966, 1969; Puertas et al., 1985) that maintain themselves by accumulation mechanisms (Jones, 1985, 1991).

B chromosomes are especially frequent in Orthoptera, where they sometimes constitute apparently stable polymorphisms (Hewitt, 1979). The grasshopper Eyprepocnemis plorans ssp. plorans shows a highly remarkable $\mathrm{B}$ chromosome polymorphism where the great majority of populations harbour B chromosomes (Camacho et al., 1997a,b). This subspecies inhabits the Mediterranean region, the Caucasus, Turkey, Turkmenistan, Iran and south-western Arabia (Dirsh, 1958). More than 40 B

*Correspondence. E-mail: jpmcamac@ugr.es chromosome variants have been described in natural Spanish populations of this grasshopper species, according to size, morphology and C-banding pattern (Henriques-Gil et al., 1984; Henriques-Gil \& Arana, 1990; López-León et al., 1993); however, only five variants have had success in establishing polymorphisms $\left(\mathrm{B}_{1}, \mathrm{~B}_{2}, \mathrm{~B}_{5}, \mathrm{~B}_{6}\right.$ and $\left.\mathrm{B}_{24}\right)$, the remaining types being found at extremely low frequency (Henriques-Gil \& Arana, 1990; López-León et al., 1993). New B variants appear frequently (López-León et al., 1993) and the replacement of a B variant by another one (Henriques-Gil \& Arana, 1990) can be caused by a detectable meiotic drive favouring the substituting variant (Zurita et al., 1998). Evidence for the monophyletic origin of most B chromosome variants, including the predominant types, has been provided by C-banding (Henriques-Gil et al., 1984; López-León et al., 1993) and fluorescent in situ hybridization (Cabrero et al., 1999).

The B chromosome polymorphism of E. plorans has provided evidence for the long-term evolution of these genome parasites as a result of an 'arms race' between them and the A genome. Thus B chromosomes, starting as parasites (possessing drive and damaging host fitness), can be neutralized because of the evolution of drive-suppressor genes in the A genome and the parallel evolution both of less damaging $\mathrm{B}$ chromosome variants and of more tolerant A genomes (Camacho et al., 1997a,b). This explains the existence of polymorphisms for B chromosome variants lacking drive (López-León et al., 1992a) and apparent effects on host fitness 
(López-León et al., 1992b; Martín-Alganza et al., 1997). These neutralized B chromosome variants, however, are condemned to random extinction and the B chromosome polymorphism would disappear unless replaced by newly arising selfish B chromosome variants (Camacho et al., 1997b). Evidence for such a regeneration of the B chromosome polymorphism has also been found in E. plorans (Zurita et al., 1998).

The geographical distribution of different B chromosome variants of this species has been extensively studied in Spain and the presence of B chromosomes has been reported in almost all natural populations analysed (Camacho et al., 1980; Henriques-Gil et al., 1984; Henriques-Gil \& Arana, 1990), the only non-B populations being located in an inland region of the Segura River basin (Cabrero et al., 1997). The single North African sample hitherto analysed (Melilla) showed the presence of a B chromosome very similar to those found in the Iberian Peninsula (Henriques-Gil \& Arana, 1990).

The present paper seeks to provide a more complete picture of B chromosome distribution in natural African populations of E. plorans. We report the presence of $\mathrm{B}$ chromosomes in all nine populations sampled from Morocco, and the existence of several lowfrequency B chromosome variants. We also perform an analysis of B chromosome frequency variation in time and space.

\section{Materials and methods}

Specimens of the grasshopper E. plorans ssp. plorans were collected at nine natural populations from northwestern Morocco during September in 1995, 1996 and 1997. The geographical location and the number of specimens caught in each of these nine populations are shown in Fig. 1 and Table 1. The populations sampled in 1995 were Smir (between Ceuta and Tetouan), Frain and SO.DE.A (close to Ksar-el-Kebir), and Mechra (close to Mechra-bel-Ksiri). In 1996 we collected grasshoppers at Ain l'abid and Tatouft (near Ksar-el-Kebir), in addition to taking new samples of the same populations sampled in 1995. In 1997, we captured new specimens from the six populations sampled in previous years and collected grasshoppers in three new sites: Larache, Asilah and Rabat.

Testes were fixed in 1:3 acetic acid-ethanol without any pretreatment. Females were injected with $0.1 \mathrm{~mL}$ of $0.05 \%$ colchicine in insect saline solution $6 \mathrm{~h}$ before fixation of the ovaries. Fixed gonadal tissues were stored at $4^{\circ} \mathrm{C}$ for at least one month before analysis.

B chromosome presence was studied by squashing testis follicles and ovarioles in acetic orcein. For characterization on the basis of morphology and C-banding patterns, gonadal tissues of B-chromosomecarrying individuals were C-banded as described by Camacho et al. (1991). The B chromosome structure was

Fig. 1 Geographical location of the nine populations of the grasshopper Eyprepocnemis plorans sampled in Morocco from 1995 to 1997. $\diamond$, Cities; -, Populations (1, Smir; 2, Asilah; 3, Larache; 4, Ain l'abid; 5, Tatouft; 6, Frain; 7, SO.DE.A; 8, Mechra; 9, Rabat). Principal rivers are also indicated.

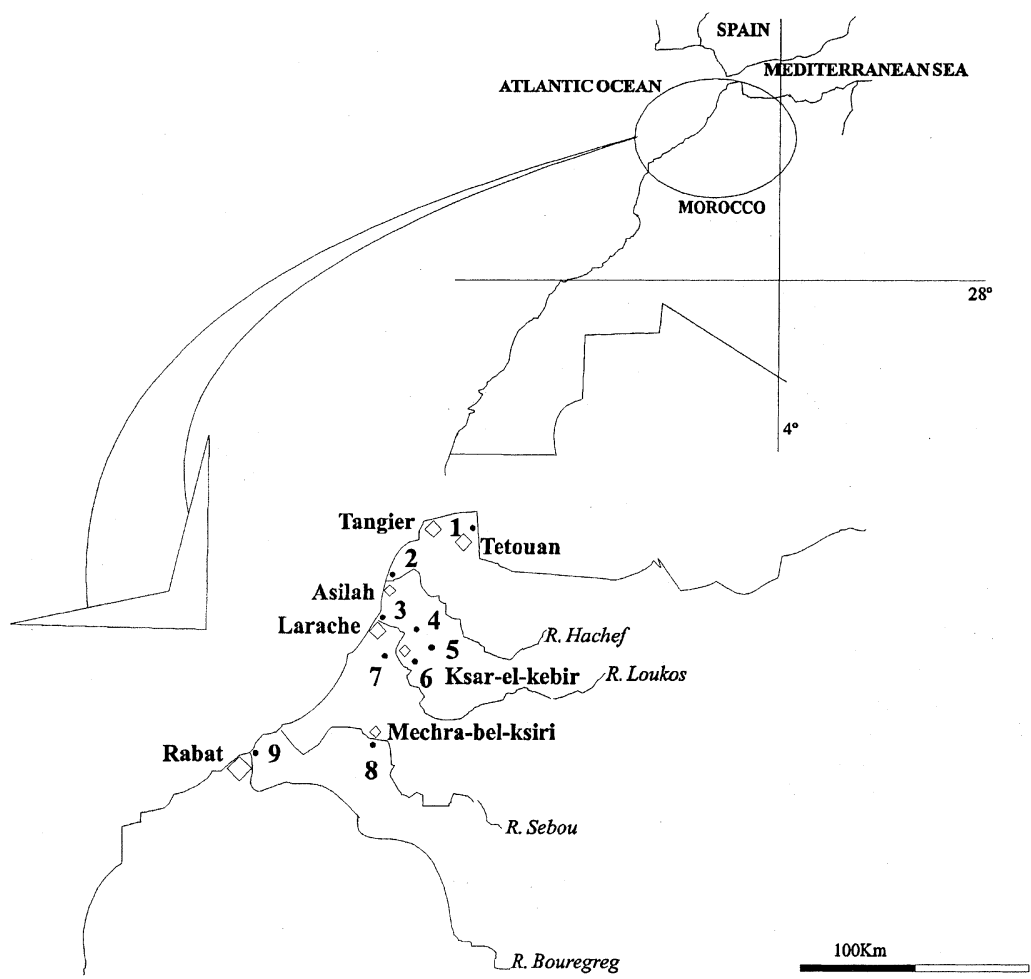

(C) The Genetical Society of Great Britain, Heredity, 83, 428-434. 
Table 1 Spatial and temporal distribution of B chromosome frequencies in specimens of the grasshopper Eyprepocnemis plorans ssp. plorans caught at nine Moroccan localities

Comparison of $\mathrm{B}_{1}$

freq. between years

\begin{tabular}{|c|c|c|c|c|c|c|c|c|c|c|c|c|c|}
\hline \multirow[b]{2}{*}{ Population } & \multirow[b]{2}{*}{ Year } & \multirow[b]{2}{*}{$0 \mathrm{~B}$} & \multirow[b]{2}{*}{ 1B } & \multirow[b]{2}{*}{$2 \mathrm{~B}$} & \multirow[b]{2}{*}{$3 B$} & \multirow[b]{2}{*}{ Total } & \multirow[b]{2}{*}{$\mathrm{B}_{1}$ freq. } & \multirow{2}{*}{$\begin{array}{l}\text { Total } \\
\text { B freq. }\end{array}$} & & \multirow{2}{*}{$\begin{array}{c}\mathrm{B}_{1} \\
\text { prevalence }\end{array}$} & \multirow{2}{*}{$\begin{array}{c}\text { Total B } \\
\text { prevalence }\end{array}$} \\
\hline & & & & & & & & & $\chi^{2}$ & d.f. & $P$ & & \\
\hline \multirow[t]{4}{*}{ Smir } & 95 & 8 & 3 & 0 & 0 & 11 & 0.273 & 0.273 & & & & 27.273 & 27.273 \\
\hline & 96 & 18 & 5 & 0 & 0 & 23 & 0.217 & 0.217 & & & & 21.739 & 21.739 \\
\hline & 97 & 21 & $10 \dagger$ & $2 \ddagger$ & $1 \S$ & 34 & 0.382 & 0.500 & & & & 32.353 & 38.235 \\
\hline & Total & 47 & 18 & 2 & 1 & 68 & 0.309 & 0.368 & 2.365 & 4 & 0.779 & 27.941 & 30.882 \\
\hline Asilah & 97 & 7 & 1 & 0 & 0 & 8 & 0.125 & 0.125 & - & - & - & 12.500 & 12.500 \\
\hline Larache & 97 & 26 & 13 & 1 & 0 & 40 & 0.375 & 0.375 & - & - & - & 35.000 & 35.000 \\
\hline \multirow[t]{3}{*}{ Ain l'abid } & 96 & 15 & 9 & 1 & 0 & 25 & 0.440 & 0.440 & & & & 40.000 & 40.000 \\
\hline & 97 & 38 & 9 ब & 0 & 0 & 47 & 0.170 & 0.192 & & & & 17.021 & 19.149 \\
\hline & Total & 53 & 18 & 1 & 0 & 72 & 0.264 & 0.278 & 5.519 & 2 & 0.055 & 25.000 & 26.389 \\
\hline \multirow[t]{3}{*}{ Tatouft } & 96 & 13 & 2 & 4 & 0 & 19 & 0.526 & 0.526 & & & & 31.579 & 31.579 \\
\hline & 97 & 26 & 12 & 2 & 0 & 40 & 0.400 & 0.400 & & & & 35.000 & 35.000 \\
\hline & Total & 39 & 14 & 6 & 0 & 59 & 0.441 & 0.441 & 5.346 & 2 & 0.080 & 33.898 & 33.898 \\
\hline \multirow[t]{4}{*}{ Frain } & 95 & 13 & 5 & 2 & 0 & 20 & 0.450 & 0.450 & & & & 35.000 & 35.000 \\
\hline & 96 & 17 & 2 & 1 & 0 & 20 & 0.200 & 0.200 & & & & 15.000 & 15.000 \\
\hline & 97 & 28 & $10 \dagger \dagger$ & 0 & 0 & 38 & 0.237 & 0.263 & & & & 23.684 & 26.316 \\
\hline & Total & 58 & 17 & 3 & 0 & 78 & 0.282 & 0.295 & 5.494 & 4 & 0.213 & 24.359 & 25.641 \\
\hline \multirow[t]{4}{*}{ SO.DE.A } & 95 & 25 & $8+t$ & 1 & 0 & 34 & 0.265 & 0.294 & & & & 23.529 & 26.471 \\
\hline & 96 & 49 & 14 & 1 & 0 & 64 & 0.250 & 0.250 & & & & 23.438 & 23.438 \\
\hline & 97 & 27 & $14 \S \S$ & 0 & 0 & 41 & 0.268 & 0.342 & & & & 26.829 & 34.146 \\
\hline & Total & 101 & 36 & 2 & 0 & 139 & 0.259 & 0.288 & 5.519 & 4 & 0.055 & 24.460 & 27.338 \\
\hline \multirow[t]{4}{*}{ Mechra } & 95 & 34 & 9 & 1 & 0 & 44 & 0.250 & 0.250 & & & & 22.727 & 22.727 \\
\hline & 96 & 54 & $25 \%$ & $5+\dagger \dagger$ & $1+t+$ & 85 & 0.400 & 0.447 & & & & 34.118 & 36.471 \\
\hline & 97 & 14 & 5 & 2 & 0 & 21 & 0.429 & 0.429 & & & & 33.333 & 33.333 \\
\hline & Total & 102 & 39 & 8 & 1 & 150 & 0.360 & 0.387 & 2.795 & 4 & 0.596 & 30.667 & 32.000 \\
\hline Rabat & 97 & 11 & $3 \S \S \S$ & 2 & 0 & 16 & 0.375 & 0.438 & - & - & - & 25.000 & 31.250 \\
\hline
\end{tabular}

†One individual carried one $\mathrm{B}_{1 \text { isol }}$.

tOne individual carried one $\mathrm{B}_{1 \text { isol }}$ and one $\mathrm{B}_{1 \text { iso2 }}$.

$\S$ This individual carried two $\mathrm{B}_{1}$ and one $\mathrm{B}_{1 \text { iso2. }}$.

TOne individual carried one $\mathrm{B}_{1 \text { iso2 }}$.

$\dagger$ †One individual carried one $\mathrm{B}_{1 \text { iso2 }}$.

t+One individual carried one $\mathrm{B}_{1 \mathrm{~d} . \mathrm{d} 1}$.

$\S \S$ Three individuals carried one $\mathrm{B}_{1 \mathrm{~d} . \mathrm{d} 1}$.

$\uparrow$ One individual carried one $\mathrm{B}_{1 \text { iso2 } 2}$.

$\dagger \dagger$ One individual carried one $\mathrm{B}_{1 \mathrm{~d} 1}$ and one $\mathrm{B}_{1 \mathrm{~d} \text {.et } 1}$.

$\$+$ This individual carried two $\mathrm{B}_{1}$ and one $\mathrm{B}_{1 \text { isol }}$.

$\S \S \S$ One individual carried one $\mathrm{B}_{3}$.

examined in male pachytene-diplotene cells, because of the less condensed state of B-chromatin in these meiotic stages.

\section{Results}

The standard chromosome complement of males and females of the grasshopper E. plorans is composed of 23 $(22+\mathrm{X} 0)$ and $24(22+\mathrm{XX})$ telocentric chromosomes, respectively.
Our study of gonadal tissues of E. plorans ssp. plorans specimens revealed the presence of B chromosomes in all nine Moroccan populations sampled. Only two individuals (Mechra-1996 and Smir-1997) were found bearing three $\mathrm{B}$ chromosomes, this being the highest number of $\mathrm{B}$ chromosomes found in the same individual (Table 1). The most frequent $\mathrm{B}$ chromosome in all nine populations was an acrocentric chromosome, about half the size of the $\mathrm{X}$ chromosome, with two proximal C-bands of similar sizes. Fluorescent in situ hybridization 


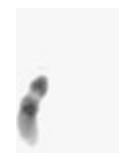

$\mathrm{B}_{1}$

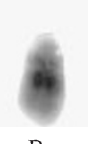

$\mathrm{B}_{1 \mathrm{~d} 1}$

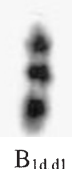

$B_{1 \text { d.d }}$

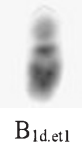

(d)

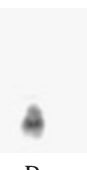

$\mathrm{B}_{3}$
$\mathrm{B}_{\text {lisol }}$

(f)

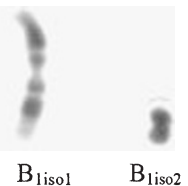

(g)
Fig. 2 C-banded B chromosome variants found in the nine Moroccan Eyprepocnemis plorans ssp. plorans natural populations sampled. (a) The most frequent B chromosome found in all the nine populations studied; (b) found in one individual in Mechra 1996; (c) found in one individual in SO.DE.A 1995 and in three from the same population in 1997; (d) present in one individual in Mechra 1996; (e) observed in one individual in Rabat 1997; (f) described as $\mathrm{B}_{12}$ and $\mathrm{B}_{1 \text { iso }}$ by Henriques-Gil et al. (1984) and López-León et al. (1993), respectively. One individual carrying this B variant was found in Mechra 1996 and two in Smir 1997; (g) one individual carried this B variant in Mechra 1996, four in Smir 1997, one in Ain l'abid 1997, and another one in Frain 1997.

analysis shows that this B chromosome is made up of the same two DNA types (rDNA and a 180-bp repeat DNA) present in B chromosomes from the Iberian Peninsula (Cabrero et al., 1999). All these data suggest that the predominant $\mathrm{B}$ chromosome in Morocco is similar (in terms of size, morphology, C-banding pattern and DNA content) to the predominant one in the Iberian Peninsula, which was named $\mathrm{B}_{1}$ by HenriquesGil et al. (1982) (Fig. 2). Temporal analysis of $\mathrm{B}_{1}$ frequency variation in Moroccan populations revealed no significant difference between years of collection in any of the six populations where this comparison could be made (Table 1). Likewise, a comparison of the frequency of individuals with different numbers of $\mathrm{B}_{1}$ chromosomes in the nine populations also failed to detect significant differences $\left(\chi_{16}^{2}=18.292 ; P=0.309\right)$. The mean prevalence (percentage of individuals carrying at least one B chromosome) was $28.32 \% \pm 2.26$, and there were no significant differences between populations $\left(\chi_{8}^{2}=3.983 ; P=0.861\right)$ or years within populations ( $P$ ranging from 0.093 to 1 ).

In addition to the principal type $\left(B_{1}\right)$, we found six other B chromosome variants (Fig. 2), for which the structure and possible mode of origin are summarized in Fig. 3.

\section{Discussion}

With the exception of the grasshoppers Atractomorpha bedeli and Acrida lata inhabiting sites heavily disturbed by human activity (Sannomiya \& Kayano, 1968), and the grasshopper Myrmeleotettix maculatus, which shows a cline movement in East Anglia (Shaw, 1983), the frequencies of most plant and animal B chromosomes that have been studied over several years have remained stable (Jones \& Rees, 1982; Cano \& Santos, 1989;
Parker et al., 1991). In the case of the grasshopper E. plorans, Camacho et al. (1997b) reported nonsignificant temporal variation in B chromosome frequency at two Spanish localities (Jete and Salobreña), sharply contrasting with another Spanish population (Torrox) where rapid changes in $\mathrm{B}_{24}$ frequency were demonstrated (Zurita et al., 1998). The nonsignificant interannual changes of the B chromosome frequency observed in the six Moroccan populations of E. plorans sampled at least twice (Smir, Ain l'abid, Tatouft, Frain, SO.DE.A and Mechra) corroborate that the time needed to record significant changes in B chromosome frequency depends on the B variant, the population, and the evolutionary status of the polymorphism at the time of sampling.

The proportion of individuals carrying B chromosomes was similar in the nine Moroccan populations studied. However, Spanish populations of this species show different local B chromosome frequency (Henriques-Gil et al., 1984; Henriques-Gil \& Arana, 1990; Camacho et al., 1997b). The low spatial differentiation in Morocco could be explained by a rapid invasion of the North African populations by the B chromosome polymorphism, together with high gene flow between the nine populations studied. This scenario is supported by the flying capacity of this grasshopper species and the absence of major geographical barriers between the nine localities. The presence of some B variants at very low frequency in some populations, and their absence in others, does not diminish the importance of gene flow as a possible cause of the spatial stability of B chromosome frequency through the Moroccan populations analysed, because these are, presumably, short-lived variants usually with low transmission efficiency (López-León et al., 1993). Thus, it is unlikely that they will migrate to other populations before disappearing. It is remarkable that the only two $\mathrm{B}$ variants detected in more than one population $\left(\mathrm{B}_{1 \text { isol }}\right.$ and $\left.\mathrm{B}_{1 \text { iso2 } 2}\right)$ are those produced by a recurrent phenomenon (centromere misdivision); they are also frequently found in Spanish populations at a very low frequency because of their low transmission ratio (LópezLeón et al., 1993). $\mathrm{B}_{1 \text { isol }}$ has been described by HenriquesGil et al. (1984) as $\mathrm{B}_{12}$ and as $\mathrm{B}_{1 \text { iso }}$ by López-León et al. (1993), and according to the code proposed by LópezLeón et al. (1993) $\mathrm{B}_{1 \text { iso2 }}$ can be considered to be a $\mathrm{B}_{\text {mini }}$.

The highly dynamic character of this $\mathrm{B}$ chromosome polymorphism (Camacho et al., 1997b) is supported by the presence of other B variants detected in some of the nine Moroccan populations studied. This dynamism of B chromosomes is an important characteristic for the maintenance of the polymorphism, because it means that a new B variant with drive can replace the principal neutralized $\mathrm{B}$ chromosome, thereby regenerating and prolonging the polymorphism life cycle (Zurita et al., 1998). 


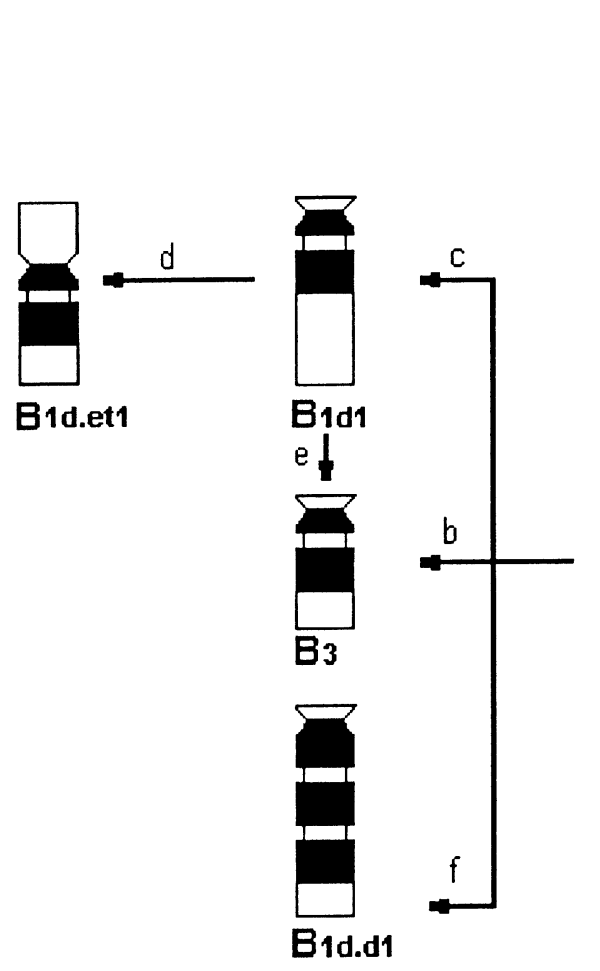

In the chive Allium schoenoprasum, Bougourd \& Parker (1979) traced with high precision the sites where B chromosomes probably originated and their mode of spreading. Despite the extensive study of many Iberian E. plorans populations, such results have not yet been achieved in this grasshopper, partly because of almost universal B chromosome presence in Spanish populations, and partly because of the scarcity of information from African populations.

Henriques-Gil et al. (1984) postulated two possibilities for the origin of the B chromosomes of E. plorans: (i) B chromosomes originated prior to the colonization of the Iberian Peninsula by this grasshopper (in this case the North African populations should have B chromosomes) or (ii) B chromosomes originated in a Spanish population and spread throughout Spain. We can add another hypothesis: (iii) B chromosomes of E. plorans originated independently in Spain and Morocco. Our study shows that $\mathrm{B}$ chromosomes are present in all the Moroccan populations studied, and the fact that the principal B chromosome found in all the studied populations is a very similar $B$ variant $\left(B_{1}\right)$ indicates that we can consider this B variant as the original B chromosome in Moroccan populations. The observed north-south continuity of $\mathrm{B}$ chromosome presence can be interpreted as the result of a migration of $\mathrm{B}_{1}$-carrying individuals through the studied populations. $\mathrm{B}_{1}$ is also considered the original B chromosome variant in Spanish natural populations (Henriques-Gil et al., 1984; López-León et al., 1993). López-León et al. (1994) proposed the X chromosome as the ancestor of the B chromosomes of the Jete and Salobreña Spanish populations. Moreover, FISH studies show that B chromosomes from Moroccan and Spanish E. plorans populations have a common origin because both are made up of the same DNA sequences (Cabrero et al., 1999). All these data lead us to deduce the possible intercontinental migration of these B chromosomes and to discard the third hypothesis.

The common origin of B chromosomes from Spain and Morocco, with $\mathrm{B}_{1}$ as the original $\mathrm{B}$ in both countries, their similar response to C-banding, their similar DNA content (Cabrero et al., 1999) and the existence of different B variants in both Spain and Morocco, indicate that the near-neutral model developed for Spanish populations (Camacho et al., 1997a,b) might be useful to apply to the polymorphism in Morocco. An inland region in the Iberian Peninsula lacking B chromosomes has been interpreted as evidence of relict populations preceding B origin, as they are isolated by geographical barriers from the B-carrying ones (Cabrero et al., 1997). This indicates that B chromosomes most likely originated after the species colonized the Iberian Peninsula, and this would run counter to hypothesis (i). The demonstration of several Spanish populations where $\mathrm{B}_{1}$ has been substituted by other $B$ variants $\left(B_{2}\right.$ in Granada province, $B_{5}$ in Fuengirola; see Henriques-Gil \& Arana, 1990), and the recent polymorphism regeneration shown in Torrox (see 
Zurita et al., 1998), indicate that the polymorphism is presumably old in Spain, so that it has reached the nearneutral stage in many populations and the regeneration stage in a few localities. In Morocco, the polymorphism shows lower $\mathrm{B}$ frequencies than in Spain, only the original $\mathrm{B}\left(\mathrm{B}_{1}\right)$ constituting a polymorphism, with no observed regeneration. The fact that $\mathrm{B}_{1}$ shows drive in some populations (Bakkali et al. unpubl. data) suggests that the B polymorphism is still in the selfish stage (the beginning) and thus it is still young in Morocco. All these facts suggest that the B polymorphism most likely arose in the Iberian Peninsula after the colonization of this species, and $B_{1}$ has recently colonized the north of Africa where the polymorphism is in the selfish starting stage of the near-neutral cycle.

\section{Acknowledgements}

M. Bakkali wishes to thank the Agencia Española de Cooperación Internacional for funding a studentship, and $\mathrm{Mr} \mathrm{S}$. Bakkali for his help in capturing specimens. This study was partially supported by grants from the Spanish Dirección General de Enseñanza Superior (no. PB96-1433) and Plan Andaluz de Investigación, Grupo no. CVI-165.

\section{References}

BOUGOURD, S. M. AND PARKER, J. S. 1979. The B chromosome system of Allium schoenoprasum. II. Stability, inheritance and phenotypic effects. Chromosoma, 75, 369-383.

CABRERO, J., LÓPEZ-LEÓN, M. D., GÓMEZ, R., CASTRO, A. J., MARTÍNAlgANZA, A. AND CAMACHO, J. P. M. 1997. Geographical distribution of $\mathrm{B}$ chromosomes in the grasshopper Eyprepocnemis plorans, along a river basin, is mainly shaped by nonselective historical events. Chromosome Res., 5, 194-198.

CABRERO, J., LÓPEZ-LEÓN, M. D., BAKKALI, M. AND CAMACHO, J.P. M. 1999. Common origin of B chromosome variants in the grasshopper Eyprepocnemis plorans. Heredity 83, 435-439.

CAMACHO, J. P. M., CARBALlO, A. R. AND CABRERO, J. 1980. The B chromosome system of the grasshopper Eyprepocnemis plorans subsp. plorans (Charpentier). Chromosoma, 80, 163-176.

CAMACHO, J. P. M., CABRERO, J., VISERAS, E., LÓPEZ-LÉON, M. D., NAVAS-CASTILlO, J. AND ALCHE, J. D. 1991. G banding in two species of grasshopper and its relationship to $\mathrm{C}, \mathrm{N}$ and fluorescence banding techniques. Genome, 34, 638-643.

CAMACHO, J. P. M., CABRERO, J., LÓPEZ-LEÓN, M. D. AND SHAW, M. W. 1997a. Evolution of a near-neutral B chromosome. Chromosomes Today, 12, pp. 301-318. Chapman \& Hall, London.

CAMACHO, J. P. M., SHAW, M. W., LÓPEZ-LEÓN, M. D., PARDO, M. C. AND CABrero, J. 1997b. Population dynamics of a selfish B chromosome neutralized by the standard genome in the grasshopper Eyprepocnemis plorans. Am. Nat., 149, 10301050 .
CANO, M. I. AND SANTOS, J. L. 1989. Cytological basis of the B chromosome accumulation mechanism in the grasshopper Heteracris litoralis (Ramb). Heredity, 62, 91-95.

DIRSH, v. M. 1958. Revision of the genus Eyprepocnemis FIEBER, 1853 (Orthoptera: Acridoidea). Proc. Roy. Ent. Soc. Lond. B, 27, 33-45.

HENRIQUES-GIL., N. AND ARANA, P. 1990. Origin and substitution of $\mathrm{B}$ chromosomes in the grasshopper Eyprepocnemis plorans. Evolution, 44, 747-753.

HENRIQUES-GIL. N., SANTOS, J. L. AND GIRALDEZ, R. 1982. B-chromosome polymorphism and interchromosomal chiasma interference in Eyprepocnemis plorans (Acrididae; Orthoptera). Chromosoma, 85, 349-359.

HENRIQUES-GIL. N., SANTOS, J. L. AND ARANA, P. 1984. Evolution of a complex B-chromosome polymorphism in the grasshopper Eyprepocnemis plorans. Chromosoma, 89, 290-293.

HEWITT, G. M. 1979. Grasshoppers and crickets. In: John, B. (ed.) Animal Cytogenetics, vol. 3, Insecta 1, Orthoptera. Gebrüder Borntraeger, Berlin.

JONES, R. N. 1985. Are B chromosomes selfish? In: CavalierSmith, T. (ed.) The Evolution of Genome Size, pp. 397-425. Wiley, London.

JONES, R. N. 1991. B Chromosome drive. Am. Nat., 137, 430-442. JONES, R. N. AND PUERTAS, M. J. 1993. The B chromosomes of Rye (Secale cereale L.). In: Dhir, K. K. and Sareen, T. S. (eds) Frontiers in Plant Science Research, pp. 81-112. Bhagwati Enterprises, Delhi, India.

JONES, R. N. AND REES, H. 1982. B Chromosomes. Academic Press, New York.

LÓPEZ-LEÓN, M. D., PARDO, M. C., CABRERO, J. AND CAMACHO, J. P. M. 1992a. Random mating and absence of sexual selection for B chromosomes in two natural populations of the grasshopper Eyprepocnemis plorans.Heredity, 69, 558-561.

LÓPEZ-LEÓN, M. D., CABRERO, J., CAMACHO, J. P. M., CANO, M. I. AND SANTOS, J. L. 1992b. A widespread B chromosome polymorphism maintained without apparent drive. Evolution, 46, 529-539.

LÓPEZ-León, M. D., CABrero, J., PARdo, M. C., VISERAS, E., CAMACHO, J. P. M. AND SANTOS, J. L. 1993. Generating high variability of $\mathrm{B}$ chromosomes in Eyprepocnemis plorans (grasshopper). Heredity, 71, 352-362.

LÓPEZ-LEÓN, M. D., NEVES, N., SCHWARZACHER, T., HESLOPHARRISON, J. S., HEWITT, G. M. AND CAMACHO, J. P. M. 1994. Possible origin of a B chromosome deduced from its DNA composition using double FISH technique. Chromosome Res., 2, 87-92.

MARTÍN-ALGANZA, A., CABRERO, J., LÓPEZ-LÉON, M. D., PERFECTTI, F. AND CAMACHO, J. P. M. 1997. Supernumerary heterochromatin does not affect several morphological and physiological traits in the grasshopper Eyprepocnemis plorans. Hereditas, 126, 187-189.

MÜNTZING, A. 1963. Effects of accessory chromosomes in a diploid and tetraploid rye. Hereditas, 49, 361-426.

NUR, U. 1966. Harmful supernumerary chromosomes in a mealy bug population. Genetics, 54, 1225-1238.

NUR, U. 1969. Harmful B-chromosomes in a mealy bug; additional evidence. Chromosoma, 28, 280-297.

ÖSTERgreN, G. 1945. Parasitic nature of extra fragment chromosomes. Bot. Notiser, 2, 157-163. 
PARKER, J. S., JONES, G. H., EDGAR, L. AND WHITEHOUSE, C. 1991. The population cytogenetics of Crepis capillaris. IV. The distribution of B-chromosomes in British populations. Heredity, 66, 211-218.

PUERTAS, M. J., ROMERA, F. AND DE LA PEÑA, A. 1985. Comparison of $\mathrm{B}$ chromosome effects on Secale cereale and Secale vavilovii. Heredity, 55, 229-234.

SANNOMIYA, M. AND KAYANO, H. 1968. Local variation and year-to-year change in frequencies of B-chromosomes in natural populations of some grasshopper species. Proc. Twelfth Int. Cong. Genet., 2, 116-117.

SHAw, M. W. 1983. Rapid movement of a B-chromosome frequency cline in Myrmeleotettix maculatus (Orthoptera: Acrididae). Heredity, 50, 14-21.

ZURITA, S., CABRERO, J., LÓPEZ-LEÓN, M. D. AND CAMACHO, J. P. M. 1998. Polymorphism regeneration for a neutralized selfish B chromosome. Evolution, 52, 274-277. 